\title{
Pentitol metabolism of Rhodobacter sphaeroides Si4: purification and characterization of a ribitol dehydrogenase
}

\author{
CORINNa Kahle, Karl-Heinz SChNeider $\dagger$ AND Friedrich GiffHorn* \\ Institut für Mikrobiologie der Universität Göttingen, Grisebachstrasse 8, D-3400 Göttingen, Germany
}

(Received 30 December 1991; revised 24 February 1992; accepted 10 March 1992)

\begin{abstract}
The phototrophic bacterium Rhodobacter sphaeroides strain Si4 induced ribitol dehydrogenase (EC 1.1.1.56) when grown on ribitol- or xylitol-containing medium. This ribitol dehydrogenase was purified to apparent homogeneity by ammonium sulphate precipitation, affinity chromatography on Procion red, and chromatography on Q-Sepharose. For the native enzyme an isoelectric point of $\mathrm{pH} 6.1$ and an apparent $M_{\mathrm{r}}$ of 50000 was determined. SDS-PAGE yielded a single peptide band of $M_{\mathrm{r}} 25000$ suggesting a dimeric enzyme structure. The ribitol dehydrogenase was specific for $\mathrm{NAD}^{+}$but unspecific as to its polyol substrate. In order of decreasing activity ribitol, xylitol, erythritol, D-glucitol and D-arabitol were oxidized. The pH optimum of substrate oxidation was 10, and that of substrate reduction was 6.5. The equilibrium constant of the interconversion of ribitol to D-ribulose was determined to be $0.33 \mathrm{nM}$ at $\mathrm{pH} \mathrm{7.0}$ and $25^{\circ} \mathrm{C}$. The $K_{\mathrm{m}}$-values determined for ribitol, ribulose, xylitol and $\mathrm{NAD}^{+}$(in the presence of ribitol) were $6.3,12.5,77$ and $0.077 \mathrm{mM}$, respectively. Because of the favourable $\boldsymbol{K}_{m}$ for ribitol, a method for quantitative ribitol determination was elaborated.
\end{abstract}

\section{Introduction}

Bacterial polyol dehydrogenases are currently being studied to test their potential use as selective reagents in enzymic analyses (Lunn et al., 1989; Schneider \& Giffhorn, 1989, 1991 ; Scheper et al., 1991 ; Berezenko \& Sturgeon, 1991), as biocatalysts in syntheses of rare sugars from polyol precursors (Izumori et al., 1990), or as model systems of experimental enzyme evolution (Rigby et al., 1974; Wawzonek Thompson \& Krawiec, 1983; Doten \& Mortlock, 1985; Loviny et al., 1985). Recently, we reported growth of the facultative phototrophic bacterium Rhodobacter sphaeroides strain $\mathrm{Si} 4$ on Dglucitol, D-mannitol and D-arabitol, and the characterization of a new mannitol dehydrogenase (EC 1.1.1.67) involved in the metabolism of these substrates. The applicability of this mannitol dehydrogenase to quantitative determination of D-mannitol was demonstrated (Schneider \& Giffhorn, 1989). In the same study it was found that $R$. sphaeroides also produced a polyol dehydrogenase active on xylitol when the organism was grown on xylitol-containing medium. Owing to the

- Author for correspondence. Present address: Institut für Angewandte Mikrobiologie, Universität des Saarlandes, D-6600 Saarbrücken, Federal Republic of Germany. Tel. 681 302 2704; fax 681 3024360 .

$\dagger$ Present address: Health Science Center Medical School, Department of Microbiology, PO Box 20708, Houston, TX 77225, USA. promising results with mannitol dehydrogenase with respect to application of the enzyme, we were interested in isolating this new $R$. sphaeroides polyol dehydrogenase and studying its properties. The results obtained are the subject of the present communication.

\section{Methods}

Organism and growth conditions. The bacterium used in this study was the purple non-sulphur bacterium Rhodobacter sphaeroides strain Si4, an isolate of this laboratory (Rode \& Gifthorn, 1983). The cells were grown routinely under chemotrophic conditions in Erlenmeyer flasks at $30^{\circ} \mathrm{C}$ with shaking (150 r.p.m.). To provide sufficient amounts of biomass for enzyme purification cells were grown under aerobic conditions in a 701 fermenter (provided by GBF, Braunschweig, FRG). Under these conditions a yield of $10 \mathrm{~g}$ wet cells $\mathrm{I}^{-1}$ was achieved.

The culture medium contained the following components in a final volume of 1 litre: xylitol, $9 \mathrm{~g} ; \mathrm{KH}_{2} \mathrm{PO}_{4}, 1 \mathrm{~g} ; \mathrm{NH}_{4} \mathrm{Cl}, 1 \mathrm{~g}$; $\mathrm{MgSO}_{4} .7 \mathrm{H}_{2} \mathrm{O}, 0.4 \mathrm{~g} ; \mathrm{NaCl}, 0.4 \mathrm{~g} ; \mathrm{CaCl}_{2} .2 \mathrm{H}_{2} \mathrm{O}, 0.05 \mathrm{~g}$; trace element solution (tenfold concentrated), $1 \mathrm{ml}$ (Pfennig \& Lippert, 1966); vitamin solution (tenfold concentrated), $1 \mathrm{ml}$ (Rode \& Giffhorn, 1983). The $\mathrm{pH}$ was adjusted to 6.8 with $\mathrm{NaOH}$. Solid media were prepared by addition of $1.5 \%(w / v)$ agar. Although the organism grew better with ribitol, we used the much cheaper xylitol as the carbon source.

Enzyme assays. Ribitol dehydrogenase activity was measured spectrophotometrically by following the absorbance change of NADH at $265 \mathrm{~nm}\left(\varepsilon=3.4 \times 10^{3} 1 \mathrm{~mol}^{-1} \mathrm{~cm}^{-1}\right)$. The standard assay mixture for substrate oxidation contained in a final volume of $1 \mathrm{ml}$ at $30^{\circ} \mathrm{C}$ : $100 \mu$ mol piperazine hydrochloride buffer (pH 9.0), 1.8 $\mu \mathrm{mol} \mathrm{NAD}{ }^{+}$ 
and $0.02-0 \cdot 2 \mathrm{U}$ ribitol dehydrogenase. The reaction was started by the addition of $150 \mu \mathrm{mol}$ ribitol.

The standard assay mixture for substrate reduction contained in a final volume of $1 \mathrm{ml}$ at $30^{\circ} \mathrm{C}: 100 \mu \mathrm{mol}$ potassium phosphate buffer (pH 6.5), $0.28 \mu \mathrm{mol}$ NADH and 0.02-0.2 U ribitol dehydrogenase. The reaction was started by the addition of $100 \mu \mathrm{mol} \mathrm{D}$-ribulose.

One unit (U) of enzyme activity was defined as the amount of enzyme required to reduce/oxidize $1 \mu \mathrm{mol}$ of $\mathrm{NAD}^{+} / \mathrm{NADH}$ per min under standard assay conditions.

Protein determination. Protein was determined by the method of Goa (1953). Crystalline bovine serum albumin was employed as the standard.

Purification of the ribitol dehydrogenase. Potassium phosphate buffer $(20 \mathrm{~mm}, \mathrm{pH} 7.4)$ was used as the standard buffer. For enzyme purification $30 \mathrm{~g}$ frozen cells were thawed and suspended in $80 \mathrm{ml}$ standard buffer to which $0.1 \mathrm{mg}$ DNAase $\mathrm{ml}^{-1}$ was added, and disintegrated by passage through a French pressure cell at $15500 \mathrm{~N} \mathrm{~cm}^{-2}$. Cell debris was removed at $5{ }^{\circ} \mathrm{C}$ by centrifugation at $27500 \mathrm{~g}$ for $1 \mathrm{~h}$.

Unless specified otherwise all following operations were carried out at room temperature.

Step 1. During stirring on ice, saturated ammonium sulphate solution was added dropwise to the crude extract up to a final concentration of $30 \%$ saturation. The precipitate was removed by centrifugation at $27500 \mathrm{~g}$, and and supernatant was dialysed at $4^{\circ} \mathrm{C}$ against standard buffer.

Step 2. The dialysed protein solution from step 1 was applied to an affinity column (Procion red, $1.6 \times 14 \mathrm{~cm}$ ) equilibrated with $20 \mathrm{~mm}$ standard buffer. The ribitol dehydrogenase was eluted with $500 \mathrm{ml}$ of a linear $\mathrm{KCl}$ gradient $(0-2 \mathrm{M})$ in standard buffer. Fractions containing high ribitol dehydrogenase activities were combined, concentrated by ultrafiltration using a PM 10 membrane (Amicon Corp.) and dialysed at $4{ }^{\circ} \mathrm{C}$ against standard buffer. During chromatography on Procion red, the bulk of mannitol dehydrogenase appeared in the washing buffer while ribitol dehydrogenase was eluted with the gradient.

Step 3. The concentrated enzyme solution was applied to a QSepharose column $(1.6 \times 7 \mathrm{~cm})$ equilibrated with standard buffer. The enzyme was eluted using $400 \mathrm{ml}$ of a linear $\mathrm{KCl}$ gradient $(0-0.6 \mathrm{M}$ in standard buffer). Fractions containing high enzyme activity were pooled, concentrated and dialysed as specified above.

Determination of $M_{r}$. The $M_{\mathrm{r}}$ of ribitol dehydrogenase was determined by gel filtration on a Superose 12 column with FPLC (Pharmacia). Standards of known $M_{\mathrm{r}}$ were catalase (240000), aldolase (158000), bovine serum albumin (68000) and ovalbumin (45000).

Gel electrophoresis. Analytical PAGE was carried out in $7.5 \%(\mathrm{w} / \mathrm{v})$ continuous gels $(0.5 \times 8 \mathrm{~cm})$ using the Tris-barbituric acid system (Maurer, 1968). The gels were run for $2 \mathrm{~h}$ at a current of $2 \mathrm{~mA}$ per tube. For activity staining of the ribitol dehydrogenase the gels were incubated for $30 \mathrm{~min}$ in a staining solution containing the following components in a final volume of $10 \mathrm{ml}: 1 \mathrm{mmol}$ Tris $/ \mathrm{HCl}$ (pH 9.0), $18 \mu \mathrm{mol} \mathrm{NAD}^{+}, 1 \mathrm{mg}$ nitro-blue tetrazolium chloride, $0.01 \mathrm{mg} 5-$ methylphenazonium methylsulphate, $1 \mathrm{mmol}$ ribitol (Gabriel, 1971).

SDS-PAGE was performed in $7.5 \%(w / v)$ vertical slab gels (Laemmli, 1970). The gels were run for $2 \mathrm{~h}$ at a current of $25 \mathrm{~mA}$. For determination of $M_{r}$, cytochrome c $\left(M_{\mathrm{r}} 12500\right)$, chymotrypsinogen A $\left(M_{\mathrm{r}} 25000\right)$, ovalbumin $\left(M_{\mathrm{r}} 45000\right)$ and bovine serum albumin $\left(M_{\mathrm{r}}\right.$ $68000)$ were used as standards.

Determination of the isoelectric point. Isoelectric focussing was performed in tubes $(0.5 \times 10 \mathrm{~cm})$. The gels, $7.5 \%(\mathrm{w} / \mathrm{v})$ in acrylamide, contained 6.3\%(w/v) Servalyt 3-10 (Laas \& Fast-Johansson, 1979). The anode solution was $10 \mathrm{~mm}$-iminodiacetic acid, the cathodic solution was $10 \mathrm{~mm}$-ethylenediamine. After prefocussing at a current of $1 \mathrm{~mA}$ per tube for $30 \mathrm{~min}, 5 \mu \mathrm{g}$ ribitol dehydrogenase was applied per tube. Focussing was carried out at $500 \mathrm{~V}$ for $6 \mathrm{~h}$. One gel was stained (Vesterberg et al., 1977) and a reference gel was cut into $1 \mathrm{~cm}$ pieces. The $\mathrm{pH}$ gradient was determined by eluting the ampholyte from each piece with $1 \mathrm{ml}$ of a $10 \mathrm{~mm}-\mathrm{KCl}$ solution. Subsequently, the $\mathrm{pH}$ of the eluant was measured.

Thin layer chromatography. Ascending thin layer chromatography was performed on silica gel 60 slabs (Merck) with butanol/ethanol/ water (10:1:2 by vol.) as solvent (Spiro, 1966). Products of the enzymic conversions were identified by co-chromatography with authentic sugars and staining with silver nitrate reagent (Dawson et al., 1986). Samples $(10 \mu \mathrm{l})$ containing about $1.5 \mu \mathrm{g}$ D-ribulose were withdrawn from reaction mixtures $(30 \mathrm{~min})$ consisting of $1 \mu \mathrm{mol}$ ribitol, $20 \mathrm{U}$ ribitol dehydrogenase and $15 \mu \mathrm{mol} \mathrm{NAD}{ }^{+}$in the standard assay buffer.

Chemicals and enzymes. The coenzymes, enzymes and molecular mass standards were purchased from Boehringer Mannheim. DRibulose and D-xylulose were obtained from Fluka. The polyols and other sugars, Serva blue G and Servalyt 3-10 were purchased from Serva; Q-Sepharose and Superose 12 were from Pharmacia; Procion red from Deutsche ICI. The other chemicals were of analytical grade and obtained from Merck.

\section{Results}

\section{Growth of $R$. sphaeroides Si4 on xylitol and ribitol and detection of a ribitol dehydrogenase activity}

Fig. 1 illustrates growth of the facultative phototrophic bacterium $R$. sphaeroides $\mathrm{Si} 4$ in mineral salts media on the pentitols xylitol and ribitol with rates of $0 \cdot 15 \mathrm{~h}^{-1}$ and $0.22 \mathrm{~h}^{-1}$, respectively. Apparently, growth on xylitol was significantly slower than growth on ribitol and it was preceded by an extended lag-phase of approximately $10 \mathrm{~h}$ when inocula from D-glucitol-grown cultures were used. Cell extracts from either culture revealed the presence of both xylitol and ribitol dehydrogenase in similar ratios of activities of about 1:5. This finding led to the assumption that both activities were expressions of the same enzyme.

\section{Purification of the ribitol dehydrogenase}

Enzyme purification was started from a batch of $30 \mathrm{~g}$ wet cells. Details of the purification procedure are described in Methods, and the results are summerized in Table 1. Accordingly, the enzyme was purified 310 -fold to a specific activity of $59 \mathrm{U}(\mathrm{mg} \text { protein })^{-1}$ with a recovery of $45 \%$. The mannitol dehydrogenase was separated from the ribitol dehydrogenase by affinity chromatography during which the bulk of the mannitol dehydrogenase was eluted in the washing buffer (see Methods). Final purification of the ribitol dehydrogenase was achieved by chromatography on Q-Sepharose. This enzyme preparation was homogeneous as shown by native-PAGE (Fig. 2) and SDS-PAGE (data not shown), 


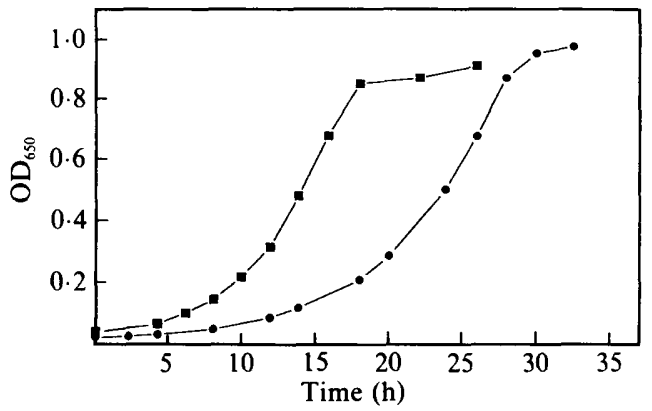

Fig. 1. Growth of $R$. sphaeroides on ribitol ( $\square$ ) and xylitol (O). The organism was grown chemotrophically in $300 \mathrm{ml}$ Erlenmeyer flasks at $30^{\circ} \mathrm{C}$ with shaking (150 r.p.m.). A mineral medium containing $2 \mathrm{~g}$ polyol $\mathrm{l}^{-1}$ was used.

Table 1. Purification of a ribitol dehydrogenase from $R$. sphaeroides Si4

\begin{tabular}{lcrcccc}
\hline \hline & $\begin{array}{c}\text { Total } \\
\text { activity* } \\
\text { Fraction }\end{array}$ & $\begin{array}{c}\text { Total } \\
\text { protein } \\
(\mathrm{mg})\end{array}$ & $\begin{array}{c}\text { Specific } \\
\text { activity } \\
\left(\mathrm{U} \mathrm{mg}^{-1}\right)\end{array}$ & $\begin{array}{c}\text { Purification } \\
(- \text {-fold })\end{array}$ & $\begin{array}{c}\text { Yield } \\
(\%)\end{array}$ \\
\hline $\begin{array}{l}\text { Crude extract } \\
\text { Ammonium sulphate } \\
\text { precipitation }\end{array}$ & 245 & 1321 & 0.19 & 1 & 100 \\
$\begin{array}{c}\text { Chromatography } \\
\text { on Procion red }\end{array}$ & 231 & 650 & 0.38 & 2 & 100 \\
$\begin{array}{c}\text { Chromatography } \\
\text { on Q-Sepharose }\end{array}$ & 111 & 1.9 & 59.0 & 310 & 45 \\
\hline \hline
\end{tabular}

* Enzyme activity was assayed with ribitol as the substrate.

each yielding a single protein band. Since the xylitol dehydrogenase activity was co-purified in a constant ratio of about $1: 5$ with the ribitol dehydrogenase activity it was concluded that both activities were properties of the same enzyme.

\section{Properties of the ribitol dehydrogenase}

The $M_{\mathrm{r}}$ of the native ribitol dehydrogenase was determined to be 50000 by gel filtration on Superose 12 with FPLC. Since SDS-PAGE gave a single band whose mobility corresponded to a $M_{\mathrm{r}}$ value of 25000 , it was concluded that the $R$. sphaeroides $\mathrm{Si} 4$ ribitol dehydrogenase is a dimeric enzyme. The isoelectric point was estimated to be $\mathrm{pH} 6 \cdot 1$.

The stability of ribitol dehydrogenase was tested in standard buffer at $4,25,40,50$ and $60^{\circ} \mathrm{C}$. Fifty percent of the initial enzyme activities were retained after incubation of $15 \mathrm{~d}, 25 \mathrm{~h}, 210,27$ and $1 \mathrm{~min}$, respectively. During storage of frozen cells at $-20^{\circ} \mathrm{C}$ the ribitol dehydrogenase lost about $50 \%$ of its initial activity within 4 months.
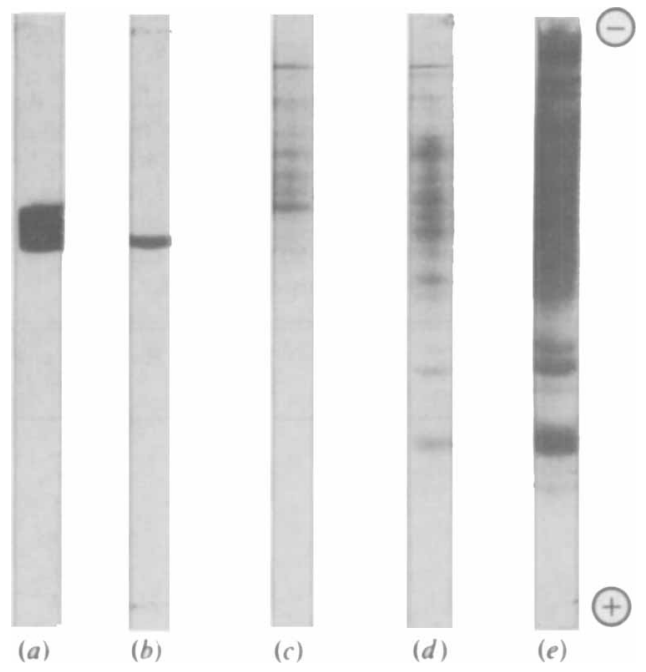

Fig. 2. Analytical PAGE of various fractions of the $R$. sphaeroides ribitol dehydrogenase purification. Gels $(7.5 \%)$ in tubes were loaded with about $20 \mu \mathrm{g}$ of protein each and run at a current of $2 \mathrm{~mA}$ (for further details see Methods). (a) Activity staining of the gel with nitroblue tetrazolium (Gabriel, 1971), (b) ion exchange chromatography on Q Sepharose, (c) affinity chromatography on Procion red A, (d) ammonium sulphate precipitation and $(e)$ cell extract. Gels $b-d$ were stained for protein with Serva blue G.

The $\mathrm{pH}$ optimum of the enzyme with ribitol as the substrate was assayed in $0 \cdot 1 \mathrm{M}$-glycylglycine/piperazine/ $\mathrm{NaOH}$ buffer in a range from $\mathrm{pH} 8.0-11.5$. The ribitol dehydrogenase exhibited a plateau of optimal activity from $\mathrm{pH} 9 \cdot 0-10 \cdot 3$ with $50 \%$ activity at $\mathrm{pH} 8.0$ and 10.7 . When D-ribulose was used as the substrate assays were carried out in $0.1 \mathrm{M}$-potassium phosphate buffer in a range from $\mathrm{pH} 6 \cdot 0-8 \cdot 0$. For D-ribulose reduction an optimal $\mathrm{pH}$ of 6.5 was determined. The temperature optimum of ribitol dehydrogenase was assayed in the standard buffer for ribitol oxidation and was found to be $45^{\circ} \mathrm{C}$. Metal salts such as $\mathrm{MgSO}_{4}, \mathrm{MnSO}_{4}$ or $\mathrm{ZnSO}_{4}$ did not stimulate the activity of the ribitol dehydrogenase when added at concentrations of $1 \mathrm{mM}$. Equally, no inhibitory effect of EDTA at concentrations between 1 and $10 \mathrm{mM}$ was observed.

The ribitol dehydrogenase was highly specific for $\mathrm{NAD}^{+}$but it was relatively unspecific with respect to various polyol and sugar substrates (Table 2). Apparently, the enzyme showed a clear catalytic preference for ribitol compared to xylitol. With regard to the sugars, D-ribulose was the preferred substrate followed by D-xylulose. The product of ribitol conversion was identified as D-ribulose by co-chromatography with authentic D-ribulose (see Methods).

The rates of substrate oxidation and reduction were determined in the standard assay system at $\mathbf{p H ~ 9 . 0 ~ a n d ~}$ 6.5 , respectively. Referring to the substrates below, all 
Table 2. Substrate specificity of the ribitol dehydrogenase from $R$. sphaeroides Si4

Enzyme activities given are mean values of duplicate determinations. The tests were carried out in the standard assay systems at $\mathrm{pH} 9.0$ and 6.5, respectively (see Methods). The assays contained $1 \mu \mathrm{g}$ (corresponding to $0.06 \mathrm{U}$ which is equivalent to $100 \%$ purified ribitol dehydrogenase and the substrates indicated at saturating concentrations: $150 \mathrm{mM}$ for the polyols except galactitol $(60 \mathrm{~mm})$ and $100 \mathrm{~mm}$ for the sugars.

\begin{tabular}{lc}
\hline \hline Substrate & $\begin{array}{c}\text { Relative enzyme } \\
\text { activity (\%) }\end{array}$ \\
\hline Ribitol & 100 \\
Xylitol & 21 \\
Erythritol & 12 \\
D-Glucitol & 10 \\
D-Arabitol & 10 \\
D-Mannitol & 0 \\
Galactitol & 0 \\
m-Inositol & 0 \\
Glycerin & 0 \\
2,3-Butandiol & 0 \\
D-Ribulose & 100 \\
D-Xylulose & $60 \cdot 7$ \\
D-Fructose & $3 \cdot 6$ \\
D-Erythrose & $3 \cdot 6$ \\
D-Arabinose & $1 \cdot 7$ \\
D-Ribose & 0 \\
D-Xylose & 0 \\
D-Tagatose & 0 \\
D-Glucose & 0 \\
D-Mannose & 0 \\
D-Sorbose & 0 \\
\hline \hline
\end{tabular}

saturation curves were hyperbolic, and the corresponding double reciprocal plots were linear. The apparent $K_{\mathrm{m}}$ values determined for ribitol, xylitol and $\mathrm{NAD}^{+}$(in the presence of $100 \mathrm{~mm}$-ribitol) were $6.3,77$ and $0.077 \mathrm{mM}$, respectively. The values for D-ribulose and D-xylulose were 1.1 and $12.5 \mathrm{mM}$, respectively.

The equilibrium constant for the conversion of ribitol was determined spectrophotometrically at $340 \mathrm{~nm}$ in $100 \mathrm{mM}$-potassium phosphate buffer $\left(\mathrm{pH} \mathrm{7.0)}\right.$ ) at $25^{\circ} \mathrm{C}$ by measuring changes in the $\mathrm{NAD}^{+} / \mathrm{NADH}$ ratio. The calculation of the equilibrium constant was based on four independent determinations in which the concentrations of $\mathrm{NAD}^{+}(0 \cdot 2-2 \mathrm{mM})$ and of ribitol (1-10 mM) were varied. From the data a mean value of $0.33 \mathrm{nM}$ with a standard deviation of 0.12 was calculated.

\section{Evaluation of a method for quantitative determination of ribitol}

Quantitative conversion of varying amounts of ribitol with the ribitol dehydrogenase from $R$. sphaeroides $\mathrm{Si4}$ is possible and is illustrated in Fig. 3. The reaction was complete within $15 \mathrm{~min}$ and the change in absorbance

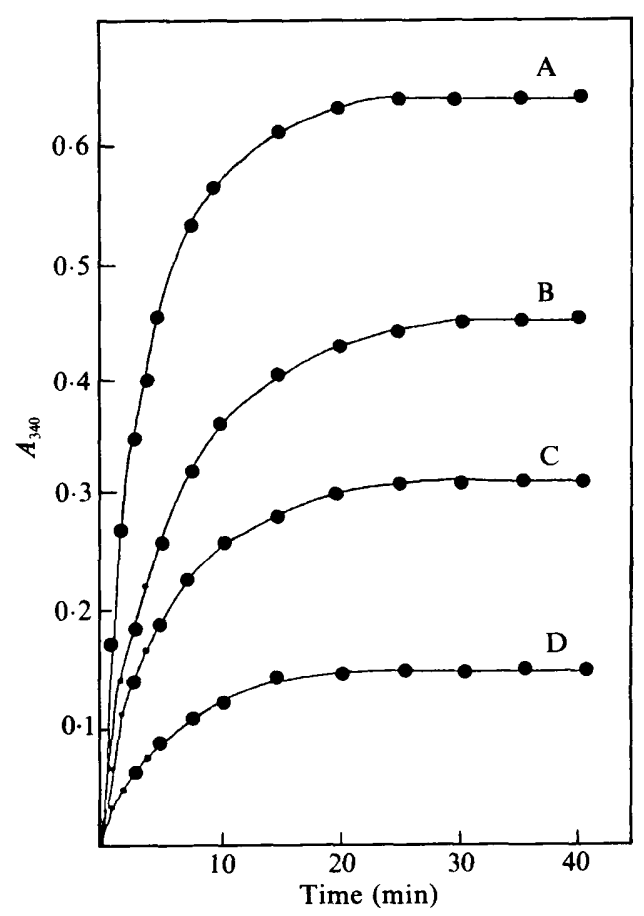

Fig. 3. Conversion of varying concentrations of ribitol by the $R$. sphaeroides ribitol dehydrogenase. The substrate conversions were performed in the standard assay system at $\mathrm{pH} 9$ (see Methods), and the change in NADH $A_{340}\left(\varepsilon=6.3 \times 10^{3} 1 \mathrm{~mol}^{-1} \mathrm{~cm}^{-1}\right)$ was recorded. The assay contained (in $1 \mathrm{ml}$ ) $2 \mathrm{U}$ ribitol dehydrogenase, and $100(\mathrm{~A})$, 75 (B), 50 (C) and 25 (D) nmol ribitol.

was strictly proportional to the amount of ribitol added. All endpoints were in agreement with the theoretical values calculated on the basis of the extinction coefficient of NADH at $340 \mathrm{~nm}$. With the customary photometric equipment the assay was sensitive enough to estimate ribitol accurately down to $10 \mathrm{nmol} \mathrm{ml}^{-1}$.

\section{Discussion}

A ribitol dehydrogenase (ribitol: $\mathrm{NAD}^{+}$2-oxidoreductase, EC 1.1.1.56) was isolated by a convenient method with good yields from $R$. sphaeroides strain Si4. The enzyme was induced by both ribitol and xylitol but it exhibited a significantly higher activity with ribitol, which was converted to D-ribulose. The $R$. sphaeroides ribitol dehydrogenase was reasonably stable and could be used as a biocatalyst for quantitative determination of ribitol. However, its stability must be significantly improved prior to use it as a biocatalyst for the preparative synthesis of D-ribulose. To our knowledge, ribitol dehydrogenases have been purified to homogencity and characterized from only the enterobacteria 
Aerobacter aerogenes (Fromm, 1958; Nordlie \& Fromm, 1959; Fromm \& Bietz, 1966) and Klebsiella aerogenes wild-type and mutant strains (Taylor et al., 1974; Burleigh et al., 1974). Therefore, we refer only to the properties of the ribitol dehydrogenases isolated from these organisms. The main differences of the ribitol dehydrogenases concern the enzyme structures. Whilst the $R$. sphaeroides ribitol dehydrogenase has a dimeric structure, the corresponding enzymes of $A$. aerogenes and $K$. aerogenes are tetramers with $M_{\mathrm{r}}$ values of about 110000 (Fromm \& Bietz, 1966; Taylor et al., 1974). On the other hand, the kinetic properties of the ribitol dehydrogenases from the different microbial sources are similar. A thorough kinetic analysis of the $K$. aerogenes ribitol dehydrogenase has been performed by Burleigh $e t$ al. (1974). The $K_{\mathrm{m}}$ values for ribitol range from 5 to $8.3 \mathrm{~mm}$ and the high $K_{\mathrm{m}}$-values for xylitol indicate the poor affinities of the enzyme towards this substrate. The slow growth of $R$. sphaeroides observed on xylitol may reflect the poor affinity of the ribitol dehydrogenase for this substrate. In this respect growth of $R$. sphaeroides on xylitol resembles that of a $K$. aerogenes mutant which metabolizes xylitol by using a weak side activity of the ribitol dehydrogenase (Wu et al., 1985; Taylor et al., 1974). Finally, it should be noted that there are a number of polyol dehydrogenases such as xylitol dehydrogenase of Serratia marcescens (Doten \& Mortlock, 1985) and aribitol dehydrogenase of Mycobacterium smegmatis (Wojtkiewicz et al., 1988) that exhibit marginal activities with ribitol.

We thank the Gesellschaft für Biotechnologische Forschung mbH, Braunschweig, FRG for performing the fermentation of $R$. sphaeroides $\mathrm{Si} 4$ in a 70 litre fermentor. This work was performed within the research centre 'Fundamentals of Biotechnology and Bioengineering' supported by a grant of the Bundesministerium für Forschung und Technologie.

\section{References}

BerezenKo, S. \& Sturgeon, R. J. (1991). The enzymic determination of D-mannitol with D-mannitol dehydrogenase from Agaricus bisporus. Carbohydrate Research 216, 505-509.

Burleigh, B. D. JR, Rigby, P. W. J. \& Hartley, B. S. (1974). A comparison of wild-type and mutant ribitol dehydrogenase from Klebsiella aerogenes. Biochemical Journal 143, 341-352.

Dawson, R. M. C., Elliot, D. C., Elliot, W. H. \& Jones, K. M. (1986). Data for Biochemical Research, 3rd edn, pp 470-479. Oxford: Clarendon Press.

Doten, R. C. \& Mortlock, R. P. (1985). Inducible xylitol dehydrogenases in enteric bacteria. Journal of Bacteriology 162, 845-848.

FromM, H. J. (1958). Ribitol dehydrogenase. 1. Purification and properties of the enzyme. Journal of Biological Chemistry 233, 1049-1052.
Fromm, H. J. \& BiETz, J. A. (1966). Ribitol dehydrogenase IV. Purification and crystallization of the enzyme. Archives of Biochemistry and Biophysics 115, 510-514.

GABRIEL, O. (1971). Locating enzymes on gels. Methods in Enzymology 22, 578-604.

GoA, J. (1953). A micro Biuret method for protein determination. Scandinavian Journal of Clinical Investigation 5, 218-222.

IZUMORI, K., Yamakita, M., Tsumura, T. \& Kobayashi, H. (1990). Production of D-psicose from D-talitol, D-tagatose or D-galactitol by Alcaligenes sp. 701B. Journal of Fermentation and Bioengineering 70, 26-29.

LaAs, T. \& Fast-Johansson, A. (1979). Isoelectric focusing with Pharmalyte ${ }^{\mathrm{TM}}$ in gel rods. In Protides of the Biological Fluids, vol. 27, pp. 693-697. Edited by H. Peeters. Oxford: Pergamon Press.

LAEMMLI, U. K. (1970). Cleavage of structure proteins during the assembly of the head of bacteriophage T4. Nature, London 227, 680-685.

LOVINY, T., Norton, P. M. \& Hartley, B. S. (1985). Ribitol dehydrogenase of Klebsiella aerogenes. Sequence of the structural gene. Biochemical Journal 230, 579-585.

LuNN, P. G., Northrop, C. A. \& Northrop, A. J. (1989). Automated enzymatic assays for the determination of intestinal permeability probes in urine 2. Mannitol. Clinica Chimica Acta 183, 163-170.

MAURER, H. R. (1968). Disk-Elektrophorese. Berlin: de Gruyter.

NordLIE, R. C. \& Fromm, H. J. (1959). Ribitol dehydrogenase II. Studies on the reaction mechanism. Journal of Biological Chemistry 234, 2523-2531.

PfenNIG, N. \& LipPeRT, K. D. (1966). Über das Vitamin B 12Bedürfnis phototropher Schwefelbakterien. Archives of Microbiology 55, 245-256.

Rigby, P. W. J., Burleigh, B. D. \& Hartley, B. S. (1974). Gene duplication in experimental enzyme evolution. Nature, London 251, 200-204.

RODE, H. \& GIFFHORN, F. (1983). Adaptation of Rhodopseudomonas sphaeroides to growth on $\mathrm{D}(-)$-tartrate and large-scale production of constitutive $\mathrm{D}(-)$-tartrate-dehydratase during growth on DL-malate. Applied and Environmental Microbiology 45, 716-719.

Scheper, T., Brandes, W., Grau, C., Hundeck, H. G., Reinhardt, B., RÜTher, F., Plötz, F., SChelp, C., SChÜGerl, K., SChNeIder, K. H., GifFHORN, F., REHR, B. \& SAHM, H. (1991). Applications of biosensor systems for bioprocess monitoring. Analytica Chimica Acta 249, 25-34.

SCHNEIDER, K. H. \& GIFFHORN, F. (1989). Purification and properties of a polyol dehydrogenase from the phototrophic bacterium Rhodobacter sphaeroides. European Journal of Biochemistry 184, 15-19.

SCHNEIDER, K. H. \& GIFFHORN, F. (1991). Sorbitol dehydrogenase from Pseudomonas spec.: purification, characterization and application to quantitative determination of sorbitol. Enzyme Microbial Technology 13, 332-337.

SPIRo, G. R. (1966). Analysis of sugars found in glycoproteins. Methods in Enzymology 8, 3-26.

TAYloR, S. S., Rigby, P. W. \& Hartley, B. S. (1974). Ribitol dehydrogenase from Klebsiella aerogenes. Purification and subunit structure. Biochemical Journal 141, 693-700.

Vesterberg, O., HANSEN, L. \& SuÖsten, A. (1977). Staining of proteins after isoelectric focussing in gels by new procedures. Biochimica Biophysica Acta 491, 160-166.

WaWzoneK Thompson, L. \& KRAWIEC, S. (1983). Acquisitive evolution of ribitol dehydrogenase in Klebsiella pneumoniae. Journal of Bacteriology 154, 1027-1031.

WotTkiewicz, B., Szmidzinski, R., Jezierska, A. \& Cocito, C. (1988). Identification of a salvage pathway for D-arabinose in Mycobacterium smegmatis. European Journal of Biochemistry 172, 197-203.

Wu, J., ANDerton-Loviny, T., SMith, C. A. \& Hartley, B. S. (1985). Structure of wild-type and mutant repressors and of the control region of the rbt operon of Klebsiella aerogenes. EMBO Journal 4, 1339-1344. 